Jorge Jobet

\title{
Monólogo del Hombre Silvestre
}

\section{I}

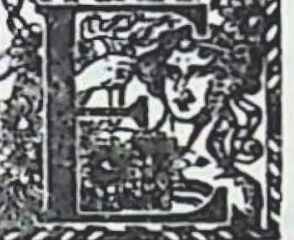

$n$ el rincón del mito, o el alero, pensado adolescente, asustadizo en ciudades sin hinojos,

tu frente de piedad, tus lágrimas de encierro, hinchando plenamente el vértice que abrigará tu envidia, tu paludismo de larva a cada instante más helada, más recóndita y precisa, como el fuego sagrado de las bailarinas impávidas, descanso de acometida, varón desengañado, obligación a lo perenne de la fuga. 
Te castiga el albatros ruidoso, oh doncel impúdico, zampoña de tubos minerales, de cestas en celo, aroma a tientas, vejiga en embarazo, tus hijos ocres ruedan en el sol desvencijado.

Quedan tus amapolas, tu cuerpo magro, el honor de tus abuelos, la tumba de tus padres, alzado encima de ellos y honrándote otra vez con sus hazañas.

Nada más que la vida y el proceso del dolor, nada más que la muerte, que imperan en tu voz, en tu sien estrangulada, como si nuestro mundo fuera sólo un escombro, sin negar la aventura, ni dormir en suspenso, el peligro o las ruinas que se ponen de moda, o este pasto del dia reviviendo tus vértigos. 


\section{II}

Los dos, extraña mía, ásperamente solos, en el peso del mito, gimiendo con decoro, aliviamos las bocas, la vejez del insomnio, el suelo envenenado de las holladas horas, sin noción de lo eterno,

o bien, divinamente, como dioses parados o demonios andrózinos.

Aún te martirizan el hogar de tu dueño, la añeja valentía del hilado incongruente, pobre fibra deseosa de estirarse en la tierra.

No sabemos de nada, ni sentimos el cielo, las veladas corrientes de algún disparadero.

Junto a mi te resignas a partir entre siervos, caceria de alforjas, 
humildad de colmena, no retienes perdidos otros fines más sobrios.

Junto a mi te avalanzas sobre lomos genéricos, con tu gracia de esclava suspirando en las cosas. No invoques la paciencia, la amargura del loto, el ideal construido de los santos blasones, la crespa levadura de nuestras tejedoras y el alacrán lampiño que tus dientes destrozan.

\section{III}

El águila, en tu entraña, linea de sombra, lame tus costados, tu astilla, tu soledad de lámpara. El águila del tiempo, en obra tan pesada, sin distinción, sin suerte, segura de sus actos, como un mendigo serio 
palpándote las manos,

el águila te muerde

el corazón sin llaves.

Te seguirá mordiendo

con real hipocresia, desde el alba a la noche,

con su pico enigmático, desde el pelo a los pies, con dulzura maligna, desde el pecho a la espalda, con la rabia del buitre, y la luna en su diestra de vigorosas garras.

Aunque niegues al cedro de otros climas calientes, con su olvido lloroso y sus largas rodillas;

aunque grabes en plomo el eslabón de los muertos, adorándose en trémolos de latidos afines, duro de realizar, y leer, y escribir con el puro cerebro; aunque te armes de furia y de espiritu angélico, tan sembrado de angustia 
como un hombre disperso, lacerado de errores y múltiples estigmas, recibirás la ciencia del brujo misionero.

\section{IV}

¿De dónde llegas, héroe, desechado, incoherente, tu augusta perla, tu ancla, tus antojos de trébol, prestancia casi incólume - los niños ocres ruedan como manes esbeltosabandonada peña, aparecida en huesos y fija en estas señas?

El amor de los castos se afila como asceta.

¿Tendrás cerca de ti las varas preferidas, el sauce atento, las normas implacables de las sacerdotisas, la leal pesadumbre del aromo macilento, el pan $y$ el vino, la razón ojerosa 
de los monasterios?

El amor de los presos se endurece en la fiebre.

¿Ahondarás el anuncio de las piraguas ardiendo, la carne desgarrada por el lúcido anzuelo? ¿Oirás la campana, el clarin incipiente, la rosa funeraria de las conquistas huérfanas?

El amor de las bestias se acomoda en las cercas.

¿ Hablará tu desprecio de almendro cejijunto, sinfonia de cascos, equivocación de lirios que vigilan tu pulso?

El amor de las niñas se adjunta a las luciérnagas.

\section{V}

Nos vamos en la brisa de pinos ventilados, cantando con la hierba. 

Ungidos, los azares, desiudan los espejos, los silenciosos cúmulos de jóvenes doncellas, estación donde habitan los pálidos inciertos.

Nos vamos. Reunidos de gozo, de tristeza, con la espina de cardo salpicada de estrellas, sin odiar lo que andamos, fingiendo la presencia de los toros echados como puños magnéticos.

\section{Jamás olvidaremos} nuestra casa silvestre curvada por el arco de la vetusta sierra. Aquí la mansedumbre de las gratas ovejas nos calmará los dedos heridos por las piedras.

Qué importan los peligros de las gordas serpientes, las cañas devastadas 
por tiesas ventoleras, el salto de los surcos de conciencia rebelde.

Tendremos que volver a crear los despojos con aquella pasión de auténtica discordia; el aliento surgido y nominal de los zorros, y la junta pendiente de los anchos desórdenes que crecen al acecho de lujosas potencias.

\section{VI}

Amado de los dioses, de los suaves profetas, esquivas la oración de las mañanas ciegas, amistad temporal de clámides ascéticas, perezoso de triunfo, ávido de cadenas, apresurando el crimen impune de los légamos, pardo de investidura marginal, de cabezas 
ahorcadas en la cruz de los injustos templos.

Monte de sacrificio, deudor de tanto clérigo, el sinsabor acude a tus designios,

a tu recia clave sádica,

a tu viril ombligo de susto desollado, como una avispa de carmín bebiéndote la sal, fúnebre transparencia de tu adúltera lombriz.

Cuelga un valle terrible bajo tus sandalias últimas, un rio de cadalsos, un puente de delicias, una escafandra ingenua copiando tus registros.

No te deshagas en el aire, cerviz domesticada, condición esencial de la hartura, fase condenable, rito de órganos terrestres en lomas de hierro rezagado. 
Giró el molino sus maderas Y atravesó los ruedos de la estancia.

Como un presagio masculino, tu posesión de espasmo, gustador de vides, de muslos transpirados, extirpador del himenio, de los rostros exangües, cuánto augur renueva tus raices, raptor molesto de la sangre.

\section{VII}

Libas en la vasija de la estrecha amargura,

y mueles en la greda de las pulpas inútiles la dádiva alumbrada de los frios helechos.

Amparador de nubes, cazador de deberes, como una marejada baña el agua tu sexo, $y$ corren las mujeres, novedosas y grávidas, a tocarte el oido con sus más dulces voces. 
Alero del benigno, constructor provechoso, deshacedor del arma colada de los próceres, el ansia en ti germina con su espiga devota, con su náyade y vaso de impoderables modos.

El destino te sobra

en la conjunción del orco

y ahuyentas a las brujas

que montan en el noto

en cien cabalgaduras

de luces multiformes.

Ensueño de la holganza, actividad del déspota, un concierto de vírgenes se inquieta en las escenas, sobre los rudos picos, bajo el semblante quieto, mientras un hombre labra su orzulloso destierro.

\section{VIII}

Ni el más leve sonido de la nieve crujiente, 
árida, endurecida, soslayando el encuentro del turbio americano de alfalfa y de centeno, ni el más leve sonido de las arañas de hebra, otro aspecto de nieve que vibra en los veneros, rasgo de reflexiones, ingénita locura de aprisionar el $\mathrm{V}$ erbo.

Espuma sin la carga de salmones deformes, las lóbregas especies recorren el ancestro de estos hijos que llevo como calvos tambores, tropezando en los sótanos y sufriendo ruta afuera.

Nadie intenta salvarme. Y la humedad me sigue. Nadie mira mi huerto. $\mathbf{Y}$ mis siembras fructifican.

Porque me estoy cayendo de bruces al sepulcro, todo lo que yo entierro, 
historia de ahora, cierta dentro de los esqueletos, todo lo que yo guardo lo matarán de nuevo.

\section{IX}

¿Quién es malo en la muerte?

Rezonga presto el eco

de las pellejerias

de sorbo a sorbo atadas,

como los mausoleos

de abruptas galerias.

Debajo de los siglos,

apenas respirando, en tálamos nupciales, con esposos benignos, laboran tenazmente las fúlgidas polillas.

Tanto tábano sucio sin espacio plausible. Tanta mugre risueña conducen los crisoles. Las heridas ancianas, indulgentes y pérfidas, anieblan el ambiente de musgo a los quelonios. 
Me parece que fueras de un antiguo correo: oleosa y peciolada, de trajinar hirsuto, como la cebra prófuga que rumia sus problemas.

Y eres más que una cita, somos más que una cuerda, acampando en la estatua de los graves silencios, apestados de orines, de molares grasosos. esperando que el indio nos cobije en su choza.

\section{X}

A veces, el camino, tendido entre los cerros, virtuosamente empuja los carros del labriego, el ánima cansada, las piernas majaderas, los codos indispuestos y aplastada la avena.

Rocas, sargas, pedruscos, con el fantasma a cuestas, 
un metódico lince su vuclo de corneja, la gente se arrodilla y quiere ir a los duelos del tiempo presumido como un joven bostezo.

Ya está la imagen suelta cernida. Ya están todos los tiernos espinazos lloviznados de estiércol, figura calumniada por malos agoreros.

La casa me atestigua como perra en destierro, $y$ no poseo fuerzas para hender sus maderas.

A veces, el camino, me aproxima al labriego, y entrambos nos hundimos en las calles del pueblo. 